INFORMASI: Kajian Ilmu Komunikasi-ISSN (p) o126-065o; ISSN (e) 2502-3837

Vol. 48. No. 2 (2018). Pp.257-266. doi: https://doi.org/10.21831/informasi.v48i2.21835

\title{
PUBLIC SERVICE ADS OF RESERVING PEAT FORESTS
}

\author{
Atika \\ atika_rusli@ulm.ac.id \\ Achmad Bayu Chandrabuwono \\ bayuchandra569@gmail.com \\ Universitas Lambung Mangkurat
}

\begin{abstract}
Social messages in Public Service Ads should be designed as appealing as possible because it affects the effectiveness of the advertisement. This study aims to investigate the attractiveness of public service advertisement of Preserving Peat Forests that are broadcast on several television stations, one of which is on Televisi Republik Indonesia Kalimantan Selatan (TVRI Kalsel). In addition to television stations, this advertisement can also be accessed through the Youtube channel of the Badan Restorasi Gambut BRG with title PSA Lestarikan Hutan Gambut which has been airing since January 7 , 2017. The study uses a quantitative approach and data were collected through surveys involving respondents who work in Peat Restoration Agency in South Kalimantan. The measurement uses a semantic differential scale. The results show that informative/ rational appeal of Public Service Ads Preserving Peat Forests is in the medium category, while the emotional appeal is rather low. Public Service Advertisement of Preserve Peat Forests which is presented through audio and visual elements is considered less able to attract audience's emotion.
\end{abstract}

Keywords: Public Service Ads, Advertising Appeal, Peat Forests

\section{DAYA TARIK IKLAN LAYANAN MASYARAKAT LESTARIKAN HUTAN GAMBUT}

\begin{abstract}
Abstrak
Pesan-pesan sosial dalam Iklan Layanan Masyarakat sebaiknya dirancang semenarik mungkin karena daya tarik sebuah iklan berpengaruh terhadap efektifitas dari iklan yang disampaikan. Tujuan penelitian ini untuk mengungkap daya tarik Iklan Layanan Masyarakat Lestarikan Hutan Gambut yang tayang di beberapa stasiun televisi, salah satunya di Televisi Republik Indonesia Kalimantan Selatan (TVRI Kalsel). Selain tayang di stasiun televisi, iklan tersebut juga dapat diakses melalui channel Youtube Badan Restorasi Gambut - BRG dengan judul PSA Lestarikan Hutan Gambut yang ditayangkan sejak tanggal 7 Januari 2017. Penelitian menggunakan pendekatan kuantitatif, dengan teknik pengumpulan data diperoleh melalui survei kepada responden dengan cakupan
\end{abstract}


wilayah kerja Badan Restorasi Gambut di Kalimantan Selatan. Skala pengukuran menggunakan skala diferensial simantik. Hasil penelitian menunjukkan bahwa daya tarik informatif/rasional Iklan Layanan Masyarakat Lestarikan Hutan Gambut berada pada kategori sedang, sementara daya tarik emosional termasuk rendah. Iklan Layanan Masyarakat Lestarikan Hutan Gambut yang disajikan melalui sejumlah elemen audio dan visual kurang mampu menarik emosional khalayaknya.

Kata Kunci: Iklan Layanan Masyarakat, Daya Tarik Iklan, Hutan Gambut

\section{PENDAHULUAN}

Hutan gambut merupakan salah satu kekayaan Indonesia yang harus dijaga kelestariannya. Sejumlah upaya dilakukan pemerintah dalam mewujudkan hutan gambut yang lestari, salah satunya dengan membentuk Badan Restorasi Gambut (BRG) melalui Peraturan Presiden Nomor 1 Tahun 2016 tentang Badan Restorasi Gambut. Lembaga yang bersifat nonstruktural tersebut mempunyai tugas mengkoordinasikan dan memfasilitasi restorasi gambut pada sejumlah daerah yang menjadi wilayah kerjanya, yaitu Provinsi Riau, Provinsi Jambi, Provinsi Sumatera Selatan, Provinsi Kalimantan Barat, Provinsi Kalimantan Tengah, Provinsi Kalimantan Selatan dan Provinsi Papua.

Pasal 3 dalam PP No. 1 Tahun 2016 tersebut mengungkapkan bahwa dalam menyelenggarakan tugasnya, BRG menyelenggarakan fungsi: 1) pelaksanaan koordinasi dan penguatan kebijakan pelaksanaan restorasi gambut; 2) perencanaan, pengendalian dan kerja sama penyelenggaraan restorasi gambut; 3) pemetaan kesatuan hidrologis gambut; 4) penetapan zonasi fungsi lindung dan fungsi budidaya; 5) pelaksanaan konstruksi infrastruktur pembasahan (rewetting) gambut dan segala kelengkapannya; 6) penataan ulang pengelolaan areal gambut terbakar; 7) pelaksanaan sosialisasi dan edukasi restorasi gambut; 8) pelaksanaan supervisi dalam konstruksi, operasi dan pemeliharaan infrastruktur di lahan konsesi; dan 9) pelaksanaan fungsi lain yang diberikan oleh Presiden.

Melalui fungsi pelaksanaan sosialisasi dan edukasi restorasi gambut pada Pasal 3 dalam PP No. 1 Tahun 2016 tersebut, BRG membuat sebuah Iklan Layanan Masyarakat yang diharapkan dapat menjadi media sosialisasi dan edukasi ke masyarakat tentang lahan gambut yang ada di Indonesia. Iklan Layanan Masyarakat yang dibuat adalah Lestarikan Hutan Gambut. Iklan tersebut tayang di beberapa stasiun televisi, salah satunya di Televisi Republik Indonesia Kalimantan Selatan (TVRI Kalsel) dengan durasi satu menit dan masa tayang iklan tanggal 16-25 April 2018. Selain tayang di stasiun televisi, iklan tersebut juga dapat diakses melalui channel Youtube Badan Restorasi Gambut - BRG pada link https:// www.youtube.com/watch?v= TEu_EuKo4Cs dengan judul PSA Lestarikan Hutan Gambut yang ditayangkan sejak tanggal 7 Januari 2017 sebagaimana terlihat pada Gambar 1 Capture PSA Lestarikan Hutan Gambut.

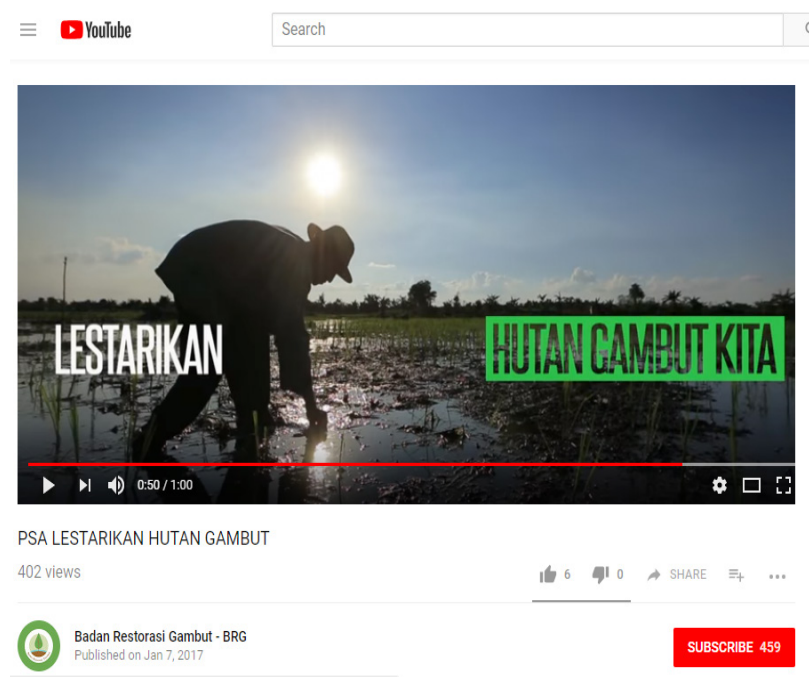

Sumber: Akun Youtube Badan Restorasi Gambut

Gambar 1 Capture PSA Lestarikan Hutan Gambut

\section{KAJIAN PUSTAKA}

Iklan Layanan Masyarakat atau Public Service Announcement (PSA) dalam Puji- 
yanto (2013) adalah iklan yang menyajikan pesan-pesan sosial yang bertujuan untuk membangkitkan kepedulian masyarakat terhadap sejumlah masalah yang harus mereka hadapi, yakni kondisi yang bisa mengecam keselarasan dan kehidupan umum. Iklan layanan masyarakat merupakan ajakan atau imbauan kepada masyarakat untuk melakukan atau tidak melakukan suatu tindakan demi kepentingan umum melalui perubahan kebiasaan atau perilaku masyarakat yang tidak/kurang baik menjadi yang lebih baik.

Ciri-ciri yang dimiliki oleh iklan layanan masyarakat oleh Pujiyanto (2013) diungkapkan sebagai berikut:

1. diangkat dari permasalahan yang ada di masyarakat

2. ada rasa kemanusiaan

3. berbagi untuk semua manusia

4. bersifat penyadaran atau menghasut (bila propaganda)

5. tidak menawarkan suatu produk

6. tidak semata-mata komersial

7. tidak memihak salah satu golongan atau agama

8. tidak memihak salah satu partai politik (kecuali propaganda)

9. targetnya adalah untuk semua lapisan masyarakat

10. berwawasan nasional

11. dikomunikasikan oleh organisasi yang telah diakui dan diterima oleh masyarakat atau Negara

12. temabisadiiklankanatau dipublikasikan

13. berdampak positif untuk kepentingan bersama sehingga memperoleh sambutan dan dukungan media massa lokal maupun nasional.

Sejumlah ciri yang disebutkan tersebut juga terdapat dalam Iklan Layanan Masyarakat Lestarikan Hutan Gambut. Iklan Layanan Masyarakat Lestarikan Hutan Gambut merupakan sebuah iklan yang diangkat dari permasalahan yang ada di masyarakat, yaitu sejumlah wilayah hutan gambut yang ada di Indonesia mengalami kerusakan, diantaranya Provinsi Riau, Provinsi Jambi, Provinsi Sumatera Selatan, Provinsi Kalimantan Barat, Provinsi Kalimantan Tengah, Provinsi Kalimantan Selatan dan Provinsi Papua., dimana ketujuh daerah tersebut juga merupakan wilayah kerja dari Badan Restorasi Gambut.

. Iklan Layanan Masyarakat Lestarikan Hutan Gambut bersifat penyadaran kepada semua lapisan masyarakat untuk senantiasa menjaga kelestarian hutan gambut. Selain itu, iklan tersebut tidak menawarkan sebuah produk yang sifatnya komersial, juga tidak memihak satu golongan, agama, dan partai politik. Hal tersebut dapat dilihat dari tayangan iklan dengan tidak menampilkan dan menawarkan sebuah produk komersial, namun berisi pesan sosial dan lingkungan untuk melestarikan hutan gambut.

Maryani et.al (2016) mengungkapkan bahwa tujuan dari iklan layanan masyarakat adalah untuk memberikan informasi dan pendidikan pada masyarakat dalam rangka mengajak masyarakat untuk berpartisipasi serta bersikap positif terhadap iklan yang ditayangkan. Selain itu, iklan layanan masyarakat bertujuan untuk menghimbau, mengingatkan mengajak masyarakat untuk tergerak melakukan hal demi terwujudnya keserasian bersama dalam masyarakat.

Untuk mencapai tujuan dari pesanpesan sosial yang disampaikan, Iklan layanan masyarakat sebaiknya dirancang dengan semenarik mungkin karena daya tarik sebuah iklan berpengaruh terhadap efektifitas dari iklan tersebut. Tinarbuko (2015) menekankan tentang pentingnya memahami siapa khalayak sasaran jika ingin membuat komunikasi visual menjadi efektif, baik khalayak sasaran secara kuantitatif maupun kualitatif.

Sejumlah penelitian tentang pengaruh daya tarik iklan sudah dilakukan dan menunjukkan bagaimana daya tarik iklan mempengaruhi efektif atau tidaknya iklan yang ditayangkan, sebagaimana yang diungkapkan dalam hasil temuan Ardiansyah, L. et.al. (2015) bahwa daya tarik iklan berpengaruh secara simultan terhadap efektifitas iklan, yaitu sejumlah indikator 
daya tarik berpengaruh terhadap efektifnya sebuah iklan. Hal serupa juga diungkapkan melalui hasil penelitian Sudiantoro (2010) bahwa daya tarik iklan berpengaruh positif terhadap efektifitas iklan, demikian juga dengan kualitas pesan iklan dan frekuensi penayangan iklan berpengaruh positif terhadap efektivitas sebuah iklan. Sufa, F. \& Munas, B. (2012) mengungkapkan hasil penelitiannya bahwa variabel daya tarik iklan memiliki pengaruh positif dan signifikan terhadap efektifitas sebuah iklan, artinya daya tarik yang baik akan meningkatkan efektivitas iklan.

Hasil penelitian tentang efektifitas iklan, khususnya iklan layanan masyarakat yang tayang di televisi diungkapkan Hastuti (2013) bahwa variabel yang paling berpengaruh dalam tayangan iklan layanan masyarakat di televisi adalah variabel daya tarik iklan. Dari hasil temuannya, Hastuty (2013) menyimpulkan bahwa iklan yang menarik akan mampu mempengaruhi perilaku audien untuk bertindak sesuai dengan maksud iklan yang disampaikan.

Kertamukti (2015) mengungkapkan tiga prinsip dalam penyusunan pesan iklan, yaitu mampu menarik perhatian (stopping power), mampu menembus minat (striking power), dan mampu memukau agar selalu diingat (sticking power). Untuk menciptakan iklan yang menarik, Hakim (2006) menulis sejumlah pendekatan yang digunakan dalam membuat lanturan-lanturan. 17 dari sejumlah pendekatan tersebut ditulis kembali oleh Kertamukti (2015), yaitu transfer, slogan, name calling, glittering generalities, plesetan, visual produk, fungsi produk, headline atau tipografi, logo, makna ganda, testimonials, plain falks, card stacking, band wagon, sex appeals, humor, dan musik.

Morissan (2014) mengelompokkan daya tarik iklan ke dalam dua kategori, yaitu daya tarik informatif/rasional (informational/ rational appeal) dan daya tarik emosional (emotional appeal). Daya tarik informatif/ rasional menekankan pada pemenuhan kebutuhan target khalayak terhadap aspek praktis, fungsional, dan kegunaan suatu produk. Sementara daya tarik emosional adalah daya tarik yang berhubungan dengan kebutuhan sosial dan psikologi target khalayak dalam penggunaan suatu produk. Jika kedua daya tarik iklan tersebut diimplementasikan ke dalam Iklan Layanan Masyarakat Lestarikan Hutan Gambut, maka penggunaan daya tarik informatif/ rasional dapat menekankan pada fakta, pembelajaran, serta logika yang cenderung bersifat informatif yang meyakinkan masyarakat bahwa hutan gambut memberi manfaat yang dapat memenuhi kebutuhan mereka. Adapun daya tarik emosional berhubungan dengan kebutuhan sosial dan psikologi masyarakat dalam melestarikan hutan gambut. Daya tarik emosional pada Iklan Layanan Masyarakat Lestarikan Hutan Gambut dapat menampilkan karakter masyarakat yang menerima manfaat emosional dari hutan gambut tersebut. Penelitian ini bertujuan untuk mengungkap daya tarik Iklan Layanan Masyarakat Lestarikan Hutan Gambut, baik dari sisi daya tarik informatif/rasional maupun dari daya tarik emosional.

\section{METODE}

Penelitian menggunakan pendekatan kuantitatif. Objek penelitian adalah Iklan Layanan Masyarakat Lestarikan Hutan Gambut yang tayang pada Televisi Republik Indonesia Kalimantan Selatan (TVRI Kalsel) yang merupakan Lembaga Penyiaran Publik di Kalimantan Selatan.

Responden dalam penelitian ini berjumlah 100 orang dari masyarakat Kalimantan Selatan yang termasuk dalam kelompok usia produktif (15-64 tahun), dengan cakupan wilayah merujuk pada data wilayah kerja Badan Restorasi Gambut di Kalimantan Selatan, yaitu Kabupaten Balangan, Kabupaten Banjar, Kabupaten Baritokuala, Kabupaten Hulu Sungai Selatan, Kabupaten Hulu Sungai Tengah, Kabupaten Hulu Sungai Utara, Kabupaten Tabalong, dan Kabupaten Tapin, sebagaimana yang terlihat dalam Peta Indikatif Prioritas Restorasi Provinsi Kalimantan Selatan pada Gambar 2. 


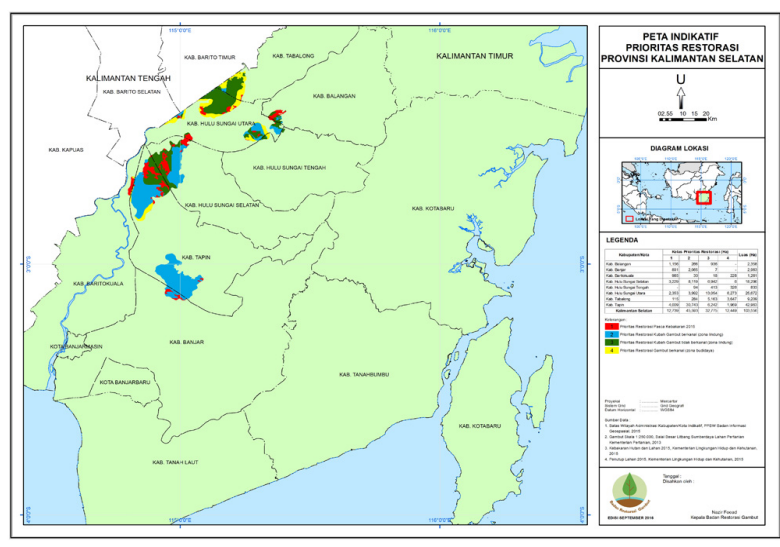

Sumber: https://brg.go.id/peta-restorasi/

Gambar 2 Peta Indikatif Prioritas Restorasi Provinsi Kalimantan Selatan

Pengumpulan data dilakukan melalui survei kepada responden yang memenuhi kriteria yang telah ditetapkan. Skala pengukuran menggunakan diferensial simantik dengan 7 skala. Pada batas bawah skala diberi label Tidak Menarik, dan pada batas atas diberi label Sangat Menarik. Pemberian label sesuai dengan apa yang diungkapkan Bordens dan Abbot (2002), bahwa ada 3 cara yang digunakan untuk memberi label pada skala rating, yaitu pemberian label pada poin akhir (end points only), pemberian label pada semua poin (each points labeled), dan pemberian label pada poin akhir dan tengah (end points and midpoint labeled). Penelitian ini menggunakan label pada poin akhir, dimana responden dapat memilih antara batas bawah sampai batas atas dari skala yang disediakan.

Penentuan skor diperoleh dari menjumlahkan hasil pilihan responden, kemudian dibuat interval tingkatan, yang diperoleh dari skor maksimum dikurangi skor minimum lalu dibagi jumlah tingkatan (rendah, sedang, tinggi), dan diperoleh hasil sebagai berikut:

Tabel 1 Data Interval Tingkat Daya Tarik Iklan Layanan Masyarakat Lestarikan Hutan Gambut

\begin{tabular}{|l|l|l|l|}
\hline Skor Min. & Skor Maks. & Interval & Kategori \\
\hline \multirow{3}{*}{358} & \multirow{3}{*}{582} & \multirow{3}{*}{75} & $358-432$ (Rendah) \\
\cline { 4 - 4 } & & & $433-507$ (Sedang) \\
\cline { 3 - 4 } & & $508-582$ (Tinggi) \\
\hline
\end{tabular}

Sumber: Hasil Penelitian, 2018

Tabel 1 menunjukkan skoryang diperoleh dari hasil penelitian ini adalah 358 sampai 582, sehingga diklasifikasikan kedalam tiga kategori daya tarik, yaitu skor 358 sampai 432 masuk dalam kategori rendah, skor 433 sampai 507 masuk dalam kategori sedang, dan skor 508 sampai 582 masuk dalam kategori tinggi.

\section{HASIL DAN PEMBAHASAN}

Kerja periklanan yang sukses menurut Mufarrih (2015) adalah iklan yang terlihat menarik dari berbagai aspek, seperti pesan yang menarik perhatian khalayaknya, visualisasi yang sesuai atau cara bernarasi yang menarik. Daya tarik iklan yang diungkapkan dalam penelitian ini mengacu pada pendapat Morissan (2014) yaitu daya tarik informatif/rasional (informational/ rational appeal) dan daya tarik emosional (emotional appeal).

Daya tarik informatif/rasional dan daya tarik emosional terlihat melalui elemen audio dan visual yang terdapat dalam Iklan Layanan Masyarakat Lestarikan Hutan Gambut tersebut. Morissan (2014) mengungkapkan bahwa elemen audio dan visual dalam suatu iklan membuka peluang untuk mewujudkan berbagai gagasan kreatif sehingga mampu menciptakan daya tarik bagi penonton. Elemen audio dalam Iklan Layanan Masyarakat Lestarikan Hutan Gambut terdiri dari suara latar musik disertai dengan narasi sebagai berikut:

1. Luas hutan gambut di Indonesia di perkirakan dua puluh koma enam juta hektar atau sepuluh koma delapan persen dari luas daratan di Indonesia

2. Hutan gambut bukan hutan biasa. Hutan gambut mampu menyimpan karbon dalam jumlah yang besar

3. Memiliki kemampuan menyerap dan menyimpan air hingga 13 kali dari bobotnya 
4. Hutan gambut mampu menyelamatkan daerah sekitarnya dari bencana banjir dan kekeringan

5. Hutan gambut bukan hutan biasa namun mengalami kerusakan yang luar biasa

6. Hutan gambut adalah sumber kehidupan bagi satwa, tumbuhan, dan juga warga yang hidup di sekitarnya

7. Sudah seharusnya kita jaga kelestariannya demi kelangsungan hidup generasi berikutnya

Elemen visual dalam Iklan Layanan Masyarakat Lestarikan Hutan Gambut terdiri dari:

1. gambar kondisi hutan gambut yang ada di Indonesia

2. tulisan "Gambut Indonesia 20.6 Juta Ha” dan tulisan "10.8 Persen Daratan Indonesia"

3. gambar kondisi hutan gambut yang mengalami kerusakan

4. gambar asapyang berasal dari kebakaran lahan gambut

5. gambar kondisi hutan gambut yang kering pasca kebakaran

6. gambar sejumlah petugas yang mengalirkan air pada lahan gambut yang terbakar

7. gambar satwa, tumbuhan, dan warga yang sedang berkebun/bertani

8. tulisan "Lestarikan Hutan Gambut Kita"

9. gambar logo dan tulisan "Badan Restorasi Gambut"

Penggunaan dua elemen tersebut dalam penelitian sebuah iklan yang merupakan karya desain komunikasi visual didukung dengan pendapat Tinarbuko (2003) yang mengungkapkan bahwa pesan yang terdapat pada berbagai karya desain komunikasi visual adalah pesan yang disampaikan kepada khalayak sasaran dalam bentuk tanda. Secara garis besar, tanda dapat dilihat dari dua aspek, yaitu tanda verbal dan tanda visual.

Hasil penelitian menunjukkan bahwa Iklan Layanan Masyarakat Lestarikan Hutan Gambut memiliki daya tarik informatif dan daya tarik emosional dengan tingkat yang berbeda dalam beberapa item elemen audio dan visual. Daya tarik informatif, secara keseluruhan termasuk dalam kategori sedang dengan skor 483.5, sementara daya tarik emosional berada pada kategori rendah dengan skor 410.1 sebagaimana terlihat pada Tabel 2.

Tabel 2 Data Interval Tingkat Daya Tarik Iklan Layanan Masyarakat Lestarikan Hutan Gambut

\begin{tabular}{|l|l|l|l|}
\hline No & Daya Tarik & Skor & Kategori \\
\hline 1 & Informatif/Rasional & 483.5 & Sedang \\
\hline 2 & Emosional & 410.1 & Rendah \\
\hline
\end{tabular}

Sumber: Hasil Penelitian, 2018

Rational approach adalah pendekatan penyampaian pesan yang mendorong khalayak menggunakan pikirannya (Kertamukti: 2015). Terdapat 12 elemen audio/visual dalam Iklan Layanan Masyarakat Lestarikan Hutan Gambutyang menggunakan daya tarik informatif/rasional sebagaimana terangkum dalam Tabel 3.

Tabel 3 Skor Daya Tarik Informatif/Rasional berdasarkan Elemen Audio dan Visual Iklan

Layanan Masyarakat Lestarikan Hutan Gambut

\begin{tabular}{|l|l|l|}
\hline No & Elemen Audio dan Visual & Skor \\
\hline 1 & $\begin{array}{l}\text { "Luas hutan gambut di Indonesia di } \\
\text { perkirakan dua puluh koma enam juta } \\
\text { hektar atau sepuluh koma delapan } \\
\text { persen dari luas daratan di Indonesia" }\end{array}$ & 572 \\
\hline 2 & $\begin{array}{l}\text { "Hutan gambut mampu menyimpan } \\
\text { karbon dalam jumlah yang besar" }\end{array}$ & 582 \\
\hline 3 & $\begin{array}{l}\text { "Memiliki kemampuan menyerap dan } \\
\text { menyimpan air hingga 13 kali dari } \\
\text { bobotnya" }\end{array}$ & 572 \\
\hline 4 & $\begin{array}{l}\text { "Hutan gambut mampu menyelamatkan } \\
\text { daerah sekitarnya dari bencana banjir } \\
\text { dan kekeringan" }\end{array}$ & 580 \\
\hline 5 & $\begin{array}{l}\text { "Hutan gambut adalah sumber } \\
\text { kehidupan bagi satwa, tumbuhan, dan } \\
\text { juga warga yang hidup di sekitarnya" }\end{array}$ & 440 \\
\hline 6 & $\begin{array}{l}\text { Gambar kondisi hutan gambut yang ada } \\
\text { di Indonesia disertai tulisan tentang luas } \\
\text { hutan gambut }\end{array}$ & 524 \\
\hline 7 & $\begin{array}{l}\text { Gambar kondisi hutan gambut yang } \\
\text { mengalami kerusakan }\end{array}$ & 552 \\
\hline 8 & $\begin{array}{l}\text { Gambarasapyang berasal dari kebakaran } \\
\text { lahan gambut }\end{array}$ & 358 \\
\hline 9 & $\begin{array}{l}\text { Gambar kondisi hutan gambut yang } \\
\text { kering pasca kebakaran }\end{array}$ & 385 \\
\hline
\end{tabular}




\begin{tabular}{|l|l|l|}
\hline 10 & $\begin{array}{l}\text { Gambar sejumlah petugas yang } \\
\text { mengalirkan air pada lahan gambut yang } \\
\text { terbakar }\end{array}$ & 374 \\
\hline 11 & $\begin{array}{l}\text { Gambar satwa, tumbuhan, dan warga } \\
\text { yang sedang berkebun/bertani }\end{array}$ & 453 \\
\hline 12 & $\begin{array}{l}\text { Gambar logo dan tulisan “Badan } \\
\text { Restorasi Gambut” }\end{array}$ & 410 \\
\hline \multicolumn{2}{|l|}{ Skor rata-rata daya tarik informatif/rasional } & 483.5 \\
\hline
\end{tabular}

Sumber: Hasil Penelitian, 2018

Keterangan:

Skor: 358-432 (rendah); 433-507 (sedang); 508582 (tinggi)

Iklan Layanan Masyarakat Lestarikan Hutan Gambut menyampaikan fakta dan informasi tentang kondisi hutan gambut di Indonesia, melalui gambar dan narasi sebagaimana yang terlihat pada Tabel 2. Hasil penelitian mengungkapkan bahwa daya tarik informatif/rasional yang berada pada kategori tinggi adalah narasi dan gambar yang menginformasikan dan menampilkan fakta tentang luas, manfaat, serta kondisi kerusakan hutan gambut seperti yang terlihat pada Gambar 3.
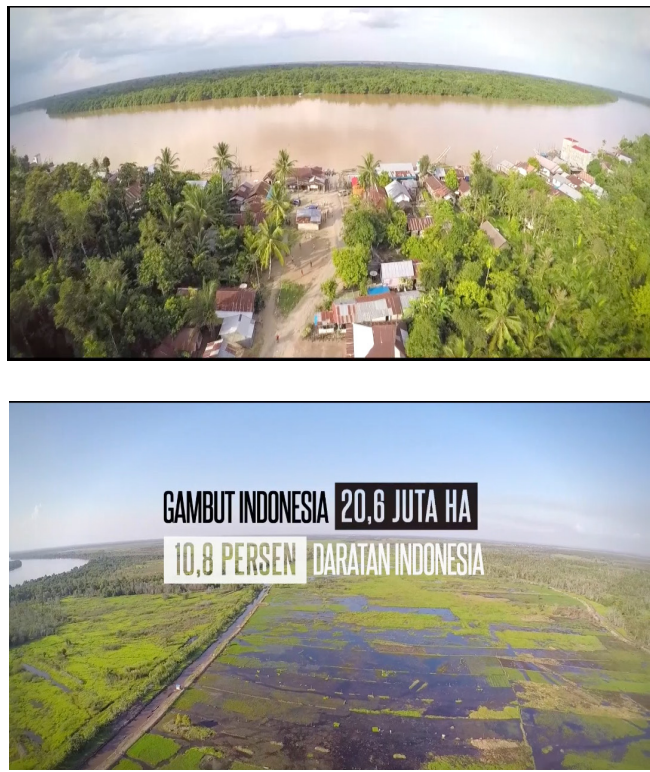

Sumber: Akun Youtube Badan Restorasi Gambut

Gambar 3 Potongan Iklan Layanan Masyarakat Lestarikan Hutan Gambut

Elemen visual yang masuk dalam kategori sedang adalah narasi dan gambar yang menampilkan sejumlah satwa, tumbuhan, dan warga yang sedang menanam seperti yang terlihat pada Gambar 4.
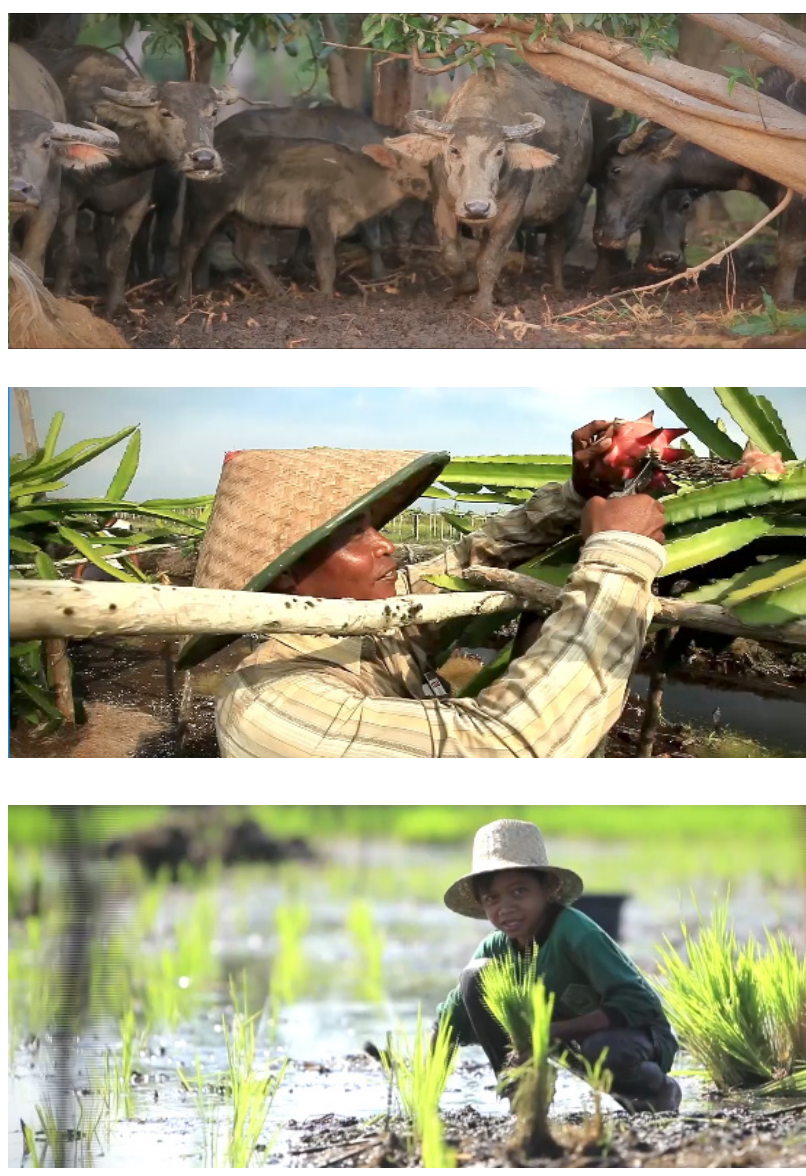

Sumber: Akun Youtube Badan Restorasi Gambut

Gambar 4 Potongan Iklan Layanan Masyarakat Lestarikan Hutan Gambut

Penggunaan daya tarik informatif/ rasional yang terlihat pada Gambar 4 berada pada tingkatan sedang, yang menunjukkan bahwa khalayak secara rasional dapat menerima bahwa hutan gambut adalah sumber kehidupan bagi satwa, tumbuhan, dan juga warga yang hidup di sekitarnya.

Daya tarik informatif/rasional dalam Iklan Layanan Masyarakat Lestarikan Hutan Gambut yang termasuk dalam kategori rendah terdapat pada empat elemen visual, yaitu pada gambar asap, gambar hutan gambut yang kering, gambar sejumlah petugas yang mengalirkan air, serta gambar logo BRG sebagaimana yang terlihat pada Gambar 5 dan Gambar 6.

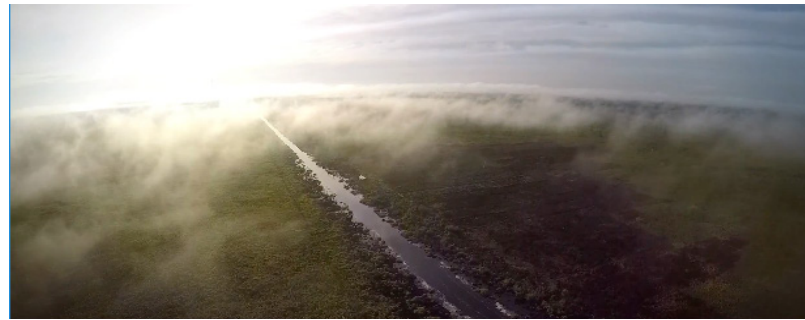



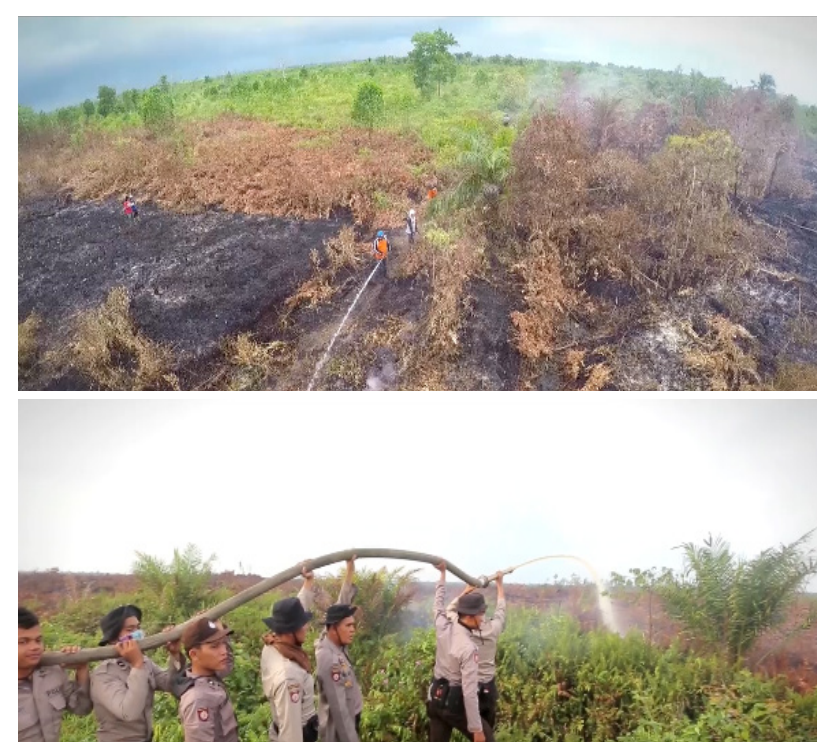

Sumber: Akun Youtube Badan Restorasi Gambut

Gambar 5 Potongan Iklan Layanan Masyarakat Lestarikan Hutan Gambut

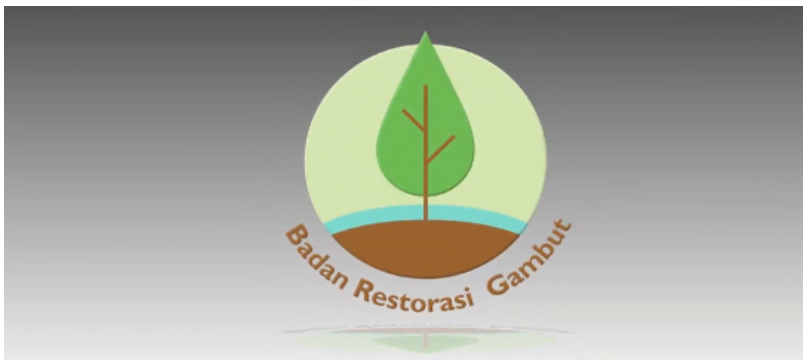

Sumber: Akun Youtube Badan Restorasi Gambut

\section{Gambar 6 Logo BRG dalam Iklan Layanan Masyarakat Lestarikan Hutan Gambut}

Belch \& Belch (2001) mengungkapkan bahwa penggunaan atribut dalam daya tarik rasional pada iklan seharusnya menekankan atau fokus pada sifat atau kualitas tertentu yang dimiliki oleh suatu barang atau jasa. Atribut yang ditampilkan melalui empat elemen visual sebagaimana yang terlihat pada Gambar 5 tersebut kurang dapat menarik dan meyakinkan khalayak tentang kondisi hutan gambut yang mengalami kerusakan, begitupun dengan gambar logo BRG (Gambar 6) sebagai pihak yang mengeluarkan Iklan Layanan Masyarakat Lestarikan Hutan Gambut kurang menarik bagi khalayak dari sisi daya tarik informatif.

Tugas utama suatu iklan layanan masyarakat, sebagaimana yang diungkapkan oleh Pujianto (2013) adalah menginformasikan pesan sosial kepada masyarakat. Iklan Layanan Masyarakat Lestarikan Hutan Gambut melalui narasi-narasi dan gambar-gambar dalam tayangnya telah menginformasikan dan menampilkan fakta tentang luas, manfaat, serta kondisi kerusakan hutan gambut. Narasi "Luas hutan gambut di Indonesia di perkirakan dua puluh koma enam juta hektar atau sepuluh koma delapan persen dari luas daratan di Indonesia" memberikan informasi kepada masyarakat bahwa hutan gambut yang dimiliki Indonesia termasuk luas dengan angka 10,8\% dari luas daratan yang ada di Indonesia. Selain itu, narasi "Hutan gambut mampu menyimpan karbon dalam jumlah yang besar. Memiliki kemampuan menyerap dan menyimpan air hingga 13 kali dari bobotnya. Hutan gambut mampu menyelamatkan daerah sekitarnya dari bencana banjir dan kekeringan" menyampaikan informasi tentang kemampuan yang dimiliki oleh hutan gambut begitu besar sehingga perlu dijaga. Informasi tersebut menjadi daya tarik bagi penonton sebagaimana yang telah diungkapkan dari hasil penelitian ini.

Kertamukti (2015) mengungkapkan salah satu pendekatan penyampaian pesan yang digunakan dalam mendorong khalayak untuk menggunakan emosinya. Terdapat tujuh elemen audio/visual dalam Iklan Layanan Masyarakat Lestarikan Hutan Gambut yang menggunakan daya tarik emosional sebagaimana terangkum dalam Tabel 4 .

Tabel 4 Skor Daya Tarik Emosional berdasarkan Elemen Audio dan Visual Iklan

Layanan Masyarakat Lestarikan Hutan Gambut

\begin{tabular}{|l|l|l|}
\hline No & Elemen Audio dan Visual & Skor \\
\hline 1 & $\begin{array}{l}\text { "Hutan gambut bukan hutan biasa namun } \\
\text { mengalami kerusakan yang luar biasa" }\end{array}$ & 402 \\
\hline 2 & $\begin{array}{l}\text { "Sudah seharusnya kita jaga kelestariannya } \\
\text { demi kelangsungan hidup generasi } \\
\text { berikutnya" }\end{array}$ & 459 \\
\hline 3 & $\begin{array}{l}\text { "Hutan gambut adalah sumber kehidupan } \\
\text { bagi satwa, tumbuhan, dan juga warga } \\
\text { sekitar" }\end{array}$ & 453 \\
\hline 4 & $\begin{array}{l}\text { Gambar asap yang berasal dari kebakaran } \\
\text { lahan gambut }\end{array}$ & 358 \\
\hline 5 & $\begin{array}{l}\text { Gambar kondisi hutan gambut yang } \\
\text { kering pasca kebakaran }\end{array}$ & 385 \\
\hline
\end{tabular}




\begin{tabular}{|l|l|l|}
\hline 6 & $\begin{array}{l}\text { Gambar sejumlah petugas yang } \\
\text { mengalirkan air pada lahan gambut yang } \\
\text { terbakar }\end{array}$ & 374 \\
\hline 7 & Tulisan “Lestarikan Hutan Gambut Kita” & 440 \\
\hline \multicolumn{2}{|l|}{ Skor rata-rata daya tarik informatif/rasional } & 410.1 \\
\hline
\end{tabular}

Sumber: Hasil Penelitian, 2018

Keterangan:

Skor: 358-432 (rendah); 433-507 (sedang); 508582 (tinggi)

Iklan Layanan Masyarakat Lestarikan Hutan Gambut menyajikan narasi dan visual yang berhubungan dengan kebutuhan sosial dan psikologi masyarakat dalam melestarikan hutan gambut, sebagaimana yang terlihat pada Tabel 3. Hasil penelitian mengungkapkan bahwa dari tujuh elemen audio/visual yang digunakan, tidak ada yang berada pada kategori tinggi. Hal tersebut menunjukkan bahwa Iklan Layanan Masyarakat Lestarikan hutan gambut kurang maksimal dalam menarik sisi emosional khalayaknya, terbukti elemen narasi tentang ajakan untuk melestarikan hutan gambut dan tulisan "Lestarikan Hutan Gambut Kita" pada akhir iklan berada pada kategori sedang. Adapun narasi tentang hutan gambut yang mengalami kerusakan luar biasa, serta gambar asap dan kondisi kerusakan hutan gambut, gambar hutan gambut yang kering, dan gambar sejumlah petugas yang sedang mengalirkan air sebagaimana terlihat pada Gambar 5 masuk dalam kategori rendah.

Rendahnya daya tarik emosional melalui visual yang disajikan dalam Iklan Layanan Masyarakat Lestarikan Hutan Gambut sebagaimana yang terlihat pada Gambar 5 menunjukkan bahwa pesan desain komunikasi visual yang disajikan kurang memiliki kesan pada publik sasarannya, sebagaimana yang diungkapkan oleh Hadi (1993) bahwa sebuah desain akan berkesan apabila dalam penyajiannya terdapat suatu kekhasan atau keunikan sehingga tampilannya mudah dibedakan dengan yang lain.

Narasi dan gambar yang menampilkan kerusakan yang terjadi pada hutan gambut di Indonesia kurang menarik sisi emosional khalayak, dimana daya tarik emosional berhubungan dengan kebutuhan sosial dan psikologi masyarakat dalam melestarikan hutan gambut. Pembuat iklan seharusnya dapat menggunakan daya tarik emosional dengan menampilkan karakter masyarakat yang menerima manfaat emosional dari hutan gambut tersebut. Selain itu, narasi dan gambar yang disajikan berupa asap dan gambar petugas lapangan kurang menyentuh sisi emosional khalayak, padahal menurut Puto dan Wells dalam Morissan (2014) bahwa salah satu ciri dari iklan transformasi yang digunakan dalam daya tarik emosional adalah iklan harus mampu menghubungkan secara kuat antara pengalaman menyaksikan iklan dengan pengalaman menggunakan produk. Iklan Layanan Masyarakat Lestarikan Hutan Gambut kurang mampu menghubungkan antara pengalaman menyaksikan iklan dengan pengalaman masyarakat di lapangan sehubungan dengan kondisi hutan gambut di lingkungan sekitarnya.

Morissan (2014) menuliskan sejumlah kelebihan yang dimiliki oleh iklan televisi, salah satunya adalah kreativitas dan efek. Kelebihan yang dimiliki tersebut membuat televisi menjadi media iklan yang paling efektif karena dapat menunjukkan cara bekerja suatu produk pada saat digunakan. Kreativitas dan efek dalam Iklan Layanan Masyarakat Lestarikan Hutan Gambut dapat ditunjukkan dengan menampilkan proses atau tahap sehingga terjadi kebakaran hutan, tidak hanya menunjukkan gambar hutan yang dalam kondisi sudah kering atau sudah terbakar.

Elemen visual yang ditunjukkan dalam Iklan Layanan Masyarakat Lestarikan Hutan Gambut yang hanya berupa gambar/foto belum maksimal menyentuh sisi emosional penonton. Masyarakat yang disasar oleh iklan tersebut tidak dapat melihat bagaimana kondisi hutan pada saat terbakar, bagaimana api dapat menghabiskan area hutan gambut, seperti apa bencana banjir dan kekeringan yang ditimbulkan dari kerusakan hutan gambut, dan seterusnya. Elemen audio yang diperdengarkan tidak disertai dengan visual yang dapat menarik emosional penonton. 


\section{SIMPULAN}

Simpulan dari penelitian ini adalah Iklan Layanan Masyarakat Lestarikan Hutan Gambut memiliki daya tarik informatif dan daya tarik emosional. Kedua daya tarik tersebut berada pada tingkat yang berbeda, dimana daya tarik informatif/rasional termasuk sedang, sementara daya tarik emosional termasuk rendah. Iklan Layanan Masyarakat Lestarikan Hutan Gambut yang disajikan melalui sejumlah elemen audio dan visual kurang mampu menarik emosional khalayaknya.

Saran untuk penelitian selanjutnya adalah objek penelitian Iklan Layanan Masyarakat Lestarikan Hutan Gambut dapat dilakukan dengan mengambil sampel dari wilayah yang berbeda, seperti Riau, Jambi, Papua, dan wilayah lainnya yang menjadi cakupan kerja Badan Restorasi Gambut.

\section{DAFTAR PUSTAKA}

Ardiansyah, L. et al. (2015). Pengaruh Daya Tarik Iklan terhadap Efektivitas Iklan. Jurnal Administrasi Bisnis (JAB), 23 (2), 75-84.

Arikunto, S. (2006). Prosedur Penelitian Suatu Pendekatan Praktek. Jakarta: PT. Rineka Cipta

Belch, G.E., Belch, M.A. (2001). Advertising and Promotion:AnIntegrated Marketing Communications Perspectives. New York: Irwin/Graw Hill.

Hadi, M.U. (1993). Tinjauan Aspek Visual Gambar Fotografi dan Gambar Tangan. Jurnal Pengetahuan dan Penciptaan Seni, BP ISI Yogyakarta. 3 (4).

Hakim, B. (2006). Lenturan tapi Relevan. Yogyakarta: Galangpress

Hastuti, S. (2013). Efektifitas Iklan Layanan Masyarakat di Televisi. Jurnal Ilmu Komunikasi. 2 (2), 67-72.

Kertamukti, R. (2015). Strategi Kreatif dalam Periklanan: Konsep Pesan, Media, Branding, Anggaran. Jakarta: Rajawali Pers.
Maryani, D. et. al. (2016). Perancangan Iklan Layanan Masyarakat untuk Orang Berusia 18-25 Tahun Agar Kritis dalam Menerima Informasi di Media Sosial. Jurnal DKV Adiwarna. 1 (8).

Morissan. (2014). Periklanan: Komunikasi Pemasaran Terpadu. Jakarta: Kencana.

Mufarrih, Z. (2015). Periklanan Sebuah Pendekatan Praktis. Yogyakarta: Buku Litera.

Sudiantoro, A. (2010). Analisis Faktor-Faktor yang Mempengaruhi Efektifitas Iklan Layanan Masyarakat Bank Indonesia Versi Ingat 3d dan Pengaruhnya Terhadap Sikap Khalayak di Kota Semarang. Semarang: Universitas Dipenogoro.

Sufa, F., \& Munas, B. (2012). Analisis Pengaruh Daya Tarik Iklan, Kualitas Pesan Iklan, Frekuensi Penayangan Iklan Terhadap Efektivitas Iklan Televisi Mie Sedap (Survei Pemirsa Iklan Mie Sedap Pada Mahasiswa Kost di Sekitar Kampus Undip, Tembalang). Diponegoro Journal Of Management, 1(4), 226-233.

Tinarbuko, S. (2003). Semiotika Analisis Tanda pada Karya Desain Komunikasi Visual. Jurnal Nirmana, 5 (1), 31-47.

Tinarbuko, S. (2015). DEKAVE Desain Komunikasi Visual - Penanda Zaman Masyarakat Global. Yogyakarta: Center for Academic Publishing Service (CAPS). 